\title{
Corrigendum: Chloroplast Glutamine Synthetase, the Key Regulator of Nitrogen Metabolism in Wheat, Performs Its Role by Fine Regulation of Enzyme Activity via Negative Cooperativity of Its Subunits
}

\author{
Edit Németh ${ }^{1,2,3}$, Zoltán Nagy ${ }^{4}$ and Attila Pécsváradi ${ }^{\text {* }}$ \\ ${ }^{1}$ Department of Plant Biology, University of Szeged, Szeged, Hungary, ${ }^{2}$ Doctoral School in Biology, Faculty of Science and \\ Informatics, University of Szeged, Szeged, Hungary, ${ }^{3}$ Centre for Agricultural Research, Hungarian Academy of Sciences, \\ Martonvásár, Hungary, ${ }^{4}$ Cereal Research Non-profit Ltd., Szeged, Hungary
}

Keywords: allosteric behavior, glutamine synthetase, negative cooperativity, nitrogen metabolism, Triticum aestivum

\section{OPEN ACCESS}

Edited and reviewed by: Frontiers in Plant Science,

Frontiers, Switzerland

*Correspondence:

Attila Pécsvárad

pecsvaradi@bio.u-szeged.hu

Specialty section

This article was submitted to Plant Metabolism and Chemodiversity,

a section of the journal

Frontiers in Plant Science

Received: 06 March 2018 Accepted: 23 March 2018

Published: 24 April 2018

Citation:

Németh E, Nagy $Z$ and Pécsváradi A

(2018) Corrigendum: Chloroplast

Glutamine Synthetase, the Key Regulator of Nitrogen Metabolism in

Wheat, Performs Its Role by Fine

Regulation of Enzyme Activity via Negative Cooperativity of Its Subunits.

Front. Plant Sci. 9:466.

doi: 10.3389/fp/s.2018.00466

\section{A corrigendum on}

Chloroplast Glutamine Synthetase, the Key Regulator of Nitrogen Metabolism in Wheat, Performs Its Role by Fine Regulation of Enzyme Activity via Negative Cooperativity of Its Subunits

by Németh, E., Nagy, Z., and Pécsváradi, A. (2018). Front. Plant Sci. 9:191. doi: $10.3389 / f p l s .2018 .00191$

In the original article, one of the authors, Dr. Dimah Z. Habash, is missing from the authors list from one of the references. The correct reference, which was cited as "(Miflin, 2002)" in the original text, is the following:

Miflin, B. J., and Habash, D. Z. (2002). The role of glutamine synthetase and glutamate dehydrogenase in nitrogen assimilation and possibilities for improvement in the nitrogen utilization of crops. J. Exp. Bot. 53, 979-987. doi: 10.1093/jexbot/53.370.979

The authors apologize for the mistake. This error does not change the scientific conclusions of the article in any way.

The original article has been updated.

Conflict of Interest Statement: The authors declare that the research was conducted in the absence of any commercial or financial relationships that could be construed as a potential conflict of interest.

Copyright () 2018 Németh, Nagy and Pécsváradi. This is an open-access article distributed under the terms of the Creative Commons Attribution License (CC BY). The use, distribution or reproduction in other forums is permitted, provided the original author(s) and the copyright owner are credited and that the original publication in this journal is cited, in accordance with accepted academic practice. No use, distribution or reproduction is permitted which does not comply with these terms. 